\title{
RIGHTS OF THE CHILD: A STUDY OF PERCEPTIONS OF MEDIA PERSONNEL
}

\author{
${ }^{1}$ Y.S.Siddegowda*, ${ }^{1}$ T.B.B.S.V. Ramanaiah, ${ }^{1}$ D. Srinivasa**, ${ }^{2}$ M. Sujatha*** \\ ${ }^{1}$ Department of Studies in Social Work, University of Mysore, India \\ ${ }^{2}$ Department of Studies in Social Work, Tumkur University, India \\ Emails:*yssgowda@yahoo.com, \\ **srinivasa.msw283@gmail.com \\ ***sujathag.savi@gmail.com
}

\begin{abstract}
The role of media personnel in spreading the knowledge about Child Rights cannot be under estimated in view of their very close contacts with people at all levels. A study is made on media personnel to know their level of knowledge and related issues of Child Rights Protection. Five hundred print media persons working in eight districts of Mysuru Revenue Division have been chosen for the study and they were administered a pre-tested questionnaire. The results indicate that the media personnel have knowledge in certain areas and are deficient in other areas. The role of media personnel, as change agents, has been explained.
\end{abstract}

Keywords: Child Right, Child Protection, Media Personnel, Child Policies and Programmes

\section{Introduction}

Child care and protection is the prime commitment of any civilized society and we can judge a society by the way it treats its children. The goal is to make this place a congenial one for children and young people to grow and develop.

India is always in the forefront in developing policies and programmes keeping in view the best interest of the children. India has demonstrated its commitment to child development by becoming to a signatory to the UN Convention on the Rights of the Child (1989) and ratified the same on $11^{\text {th }}$ December 1992.

The rights of the child include many dimensions. To be more specific, the rights include- right to family life; right to be protected from violence; right to have a say and be respected; right to health, and right to education. The rights also include protection to these children living in difficult circumstances.

The UN Convention on the Rights of the Child provides a framework of standards and principles that can facilitate in planning programmes and activities so as to improve the enjoyment of children's rights. The convention is a living reality that specifies common standards. It would guide people all over the world to deal with the child in a fair manner, and to ensure that every child is healthy and further, feels safe and protected in every way.

The convention serves as a guide for all those who have the responsibility of care and protection of children. This includes parents, teachers, police officers, media personnel, doctors etc. It is believed that everyone makes a difference. Media personnel have a unique function in educating and sensitizing the public about child rights and also in guiding the society towards establishing a safe and protected place for all children.

The role of media personnel in sensitizing the public, especially the other stakeholders in Child Rights and their importance in creating a child-friendly and child-caring environment, is an unique one indeed. Further, the media has the responsibility of reaching people and to enlightening them which would lead to positive attitude 
and practice. But, before embarking on such a noble exercise, they need to assess their level of knowledge of Child Rights and the extent of its application. Hence, the present study aims at understanding the above mentioned aspects pertaining to Child.

\section{Review of Literature}

The Australian Association of Social Workers (2013) recognizes two terms - child well-being and child protection. These two terms adequately refers to the responsibility of every right thinking person including social worker in paying attention to the well being, development and safety of children and young people. Primarily, it is the family that must be helped to grow and develop and function adequately for the care and development of children and young people.

Choudhury (2014) has endorsed that journalists are champions of human rights. Their work would encourage and facilitate both Government and civil society (organizations) to bring appropriate and positive changes so as to improve the quality of life of children. Further, the author has warned that news pertaining to children should be handled very carefully in view of media's powerful influence on the minds of viewers, especially children. Similarly, the public must be made known of the Rights of Children and the ways and means to promote them. The author concludes that the media is the best disseminator of news to all, especially of the child keeping in view the best interest of the child as its primary concern.

Awosola and Omoera (2008) have studied 200 persons, chosen at random, to understand the influence of media, especially television medium, in creating awareness among the public on the child rights and also child survival. It is observed in the study that television as a medium of communication has enhanced awareness on the rights of the child and other issues related to child development. Television programmes have not convinced people to change their way of behavior in handling children. In spite of having knowledge, corresponding change in the behavior is not to be found. It is apt to mention that improved knowledge must be converted in to improved positive action in terms of handling children.

To understand the roles of television in child rights protection Mahesh Chandra Guru et.al (2015) have studied 660 subjects of which 300 are children and 180 are parents and the remaining are other stakeholders. The study revealed that television has not shown a positive impact in terms of protection of child rights according to the parents. The authors have suggested a proper linkage between television programmes and child rights protection with a caution that media must be sensitive to the rights of children.

In a review of empirical work on the link between various types of electronic media and cognitive skills of school-age children and adolescents, Schmidt and Vandewater (2008) have observed that viewing educational television programmes is linked positively with academic achievement.

Most of the reviews on Child Rights has been studied from the view point of media personnel and more so of visual media. The print media with its wide coverage in influencing people has not been attempted as much in understanding the perceptions of media personnel in the implementations of Child Rights for the comprehensive development of children.

\section{Research Methodology}

Among the stakeholders, media personnel especially, print media have a unique role to perform in sensitizing the civil society not only in perception but also in action to the desired end in safeguarding the rights of the child. A study is undertaken to examine the level of awareness of media personnel with regard to the UN Convention on the Rights of the Child (Part-I). Further, the study is intended to know the extent of occurrence of violation of these rights as perceived by them, and to explore the ways and means to protect and promote these rights. 
The study has been carried out in the revenue of division of Mysuru, Karnataka on 500 media representatives. The selection of the media personnel is purely purposive in nature. Care is taken in identifying those people who have interest in the subject of child rights and willing to serve as a subject for the study. These media representatives hail from eight districts of revenue division of Mysuru namely Chamarajanagar, Chikmagaluru, Dhakshina Kannada, Hassan, Kodagu, Mandya, Mysuru and, Udupi.

The researchers have visited all the places and identified print media persons who are available in their respective places of work and also at a central place where representatives generally assemble to get news items. A pre-tested questionnaire, covering issues concerned with perceptions of media personnel on the implementation of UN Convention on Rights of the Child and observations made by them, was administered on all. Ethical issues of research, especially of informed consent, have been compiled with in carrying out the study.

\section{Results}

The subjects chosen for the study comprise of young, professionally well educated, with long years of standing in the field and are urban in domicile.

The characteristics indicate the maturity as well as enthusiasm of media representatives in the professional duties (Table.1).

The questionnaire findings reveal that article 1, 18, and 3 are better known to the representatives than other articles. These three articles refer to the definition of the term 'Child', family responsibility in taking care of children, and the best interest of the child are to be taken in making decisions that may affect them.

To One (2011), has mentioned that Child Rights are unique in the sense that children are 'Rights Holder' and these rights are to be properly executed by the adults. This is required keeping in view the age of the child and adults are primarily responsible for acting in their best interests. States must always project the best interest of the child at the forefront of all public policies and programs to make people aware that care of children and protection of children is the priority commitment (Table.2).

Media representatives have highlighted that they have witnessed more frequent violation of certain kinds of rights. The most commonly found violations are of deprivation of good health care and drinking water to children, children abused and neglected and children deprived of parental care and therefore, imposing the burden of their care on the state (Table.3).

Almost all media representatives have taken extra care in reporting the rights of the child and also fearlessly reported the violation whenever happened. Of all the violations reported, child labour is the most prominently reported abuse, followed by discriminations of children in school and children found begging in streets and in busy places (Table.4).

All media personnel recommend that a short term orientation programme (to all media personnel) is essential to safe guard the rights of the children. They further advocate news papers $(97.4 \%)$ as the best medium of reaching maximum people followed by television (82.2\%). In a content analysis of news and programmes of Ethiopian Television Police Programme for three years, Mulugeta (2014) has observed that Child Rights, and child abuse are not found to be the focused programmes (Table.5,6).

Most media personnel (493 or 98.6\%) are of the opinion that children have responsibilities too. Respecting elders, respecting the culture and traditions of other children, and imbibing best values in them are the important responsibilities stated. 
Media personnel have a greater role to perform in protecting and promoting Child Rights which include sensitizing elders, and cases of violation are to be reported fearlessly to contain the abuse of Child Rights. Media personnel have a positive approach to Child Rights and ways and means in protecting them (Table.7).

\section{Conclusion}

The study reveals that media personnel are aware of the rights of the children as specified by the United Nations Convention on the Rights of the Child. Further, they report cases of violation of Child Rights and they feel that media representatives have a crucial role in making the Rights of Child a reality both in letter and spirit. Press persons have close contact with public and hence, they can serve as child rights stakeholders. Further, they are the child rights advocates in view of their expertise in specific issues.

\section{References}

Australian Association of Social Workers (2013); Child Wellbeing and Protection, AASW Position Paper.

Awosola, Rasaq Koyode and Omoera, Osakue Stevenson (2008); Child Rights and the Media: The Nigerian Experience, Studies on Home and Community Science, 2(2), 125-131.

Choudhury, Pranita (2014); Impact of Media on Child, IOSR Journal of Humanities and Social Science, 19 (10), 19-24.

Mahesh Chandra Guru. B.P., Gundlupet, Madhu, Shivaraju, and Rajgopala.K., (2015); Television and Child Rights Protection: An Empirical Study of Parent's Attitude and Perceptions, International Journal of Management and Social Science Research Review, 1 (17), 211-216.

Mulugeta, Tseganesh (2014); Media Coverage of Child Abuse and Child Protection in Ethiopia, Online Journal of Communication and Media Technologies, 4 (4), 86-99.

Schmidt, Marie Evans, and Vandewater Elizabeth.A, (2008); Media and Attention, Cognition, and School Achievement, spring, 18 (1), 63-85.

Te One, Sarah (2011); Defining Rights: Children's rights in theory and in practice, He Kupu Word, ejournal, Peer-reviewed Paper, 2 (4), 41-57. 
Table 1: Characteristics of Media Representatives

\begin{tabular}{|c|c|c|c|}
\hline S1. No & Age & $\begin{array}{l}\text { No. of Persons } \\
\text { N:500 }\end{array}$ & $\%$ \\
\hline 1 & 35 years and below & 272 & 54.4 \\
\hline 2 & 36 years- 45 years & 151 & 30.2 \\
\hline \multirow[t]{2}{*}{3} & 46 years and above & 77 & 15.4 \\
\hline & Education & & \\
\hline 1 & $\mathrm{BA}$ & 122 & 24.4 \\
\hline 2 & B. Com & 23 & 4.6 \\
\hline 3 & MA & 344 & 68.8 \\
\hline \multirow[t]{2}{*}{4} & M.Com & 11 & 2.2 \\
\hline & Experience & & \\
\hline 1 & 10 years and below & 258 & 51.6 \\
\hline 2 & 11 years -20 years & 166 & 33.2 \\
\hline \multirow[t]{2}{*}{3} & 20 years and above & 76 & 15.2 \\
\hline & Place of working & & \\
\hline 1 & Urban & 372 & 74.4 \\
\hline 2 & Rural & 83 & 16.6 \\
\hline 3 & Integrated & 45 & 9.0 \\
\hline
\end{tabular}

Table 2: Awareness of Media Personnel with regard to the Rights of the Child

\begin{tabular}{|c|c|c|}
\hline Sl. No. & Articles & $\begin{array}{l}\text { No. of persons aware of the right. } \\
\text { N:500 }\end{array}$ \\
\hline 1 & 1 & 461 \\
\hline 2 & 18 & 453 \\
\hline 3 & 3 & 413 \\
\hline 4 & 19 & 383 \\
\hline 5 & 17 & 364 \\
\hline 6 & 33 & 363 \\
\hline 7 & 23 & 315 \\
\hline 8 & 28 & 264 \\
\hline 9 & 7 & 253 \\
\hline 10 & 2 & 243 \\
\hline 11 & 13 & 242 \\
\hline 12 & 5 & 235 \\
\hline 13 & 6 & 239 \\
\hline 14 & 29 & 239 \\
\hline 15 & 31 & 219 \\
\hline 16 & 12 & 218 \\
\hline 17 & 34 & 215 \\
\hline 18 & 35 & 212 \\
\hline 19 & 24 & 209 \\
\hline 20 & 40 & 203 \\
\hline
\end{tabular}




\begin{tabular}{|l|l|l|}
\hline 21 & 42 & 186 \\
\hline 22 & 27 & 185 \\
\hline 23 & 32 & 171 \\
\hline 24 & 30 & 163 \\
\hline 25 & 39 & 157 \\
\hline 26 & 4 & 155 \\
\hline 27 & 16 & 153 \\
\hline 28 & 11 & 150 \\
\hline 29 & 9 & 149 \\
\hline 30 & 25 & 143 \\
\hline 31 & 41 & 142 \\
\hline 32 & 10 & 131 \\
\hline 33 & 37 & 128 \\
\hline 34 & 8 & 123 \\
\hline 35 & 38 & 122 \\
\hline 36 & 26 & 121 \\
\hline 37 & 36 & 111 \\
\hline 38 & 14 & 100 \\
\hline 39 & 21 & 93 \\
\hline 40 & 20 & 89 \\
\hline 41 & 22 & 87 \\
\hline 42 & 15 & 73 \\
\hline & & \\
\hline
\end{tabular}

Table 3: Number of persons who have either witnessed / heard from reliable Sources the Violation of Rights

\begin{tabular}{|l|l|l|}
\hline Sl. No. & Article & No. of Media Personnel N: 500 \\
\hline 1 & 24 & 285 \\
\hline 2 & 39 & 266 \\
\hline 3 & 18 & 240 \\
\hline 4 & 38 & 232 \\
\hline 5 & 28 & 198 \\
\hline 6 & 26 & 184 \\
\hline 7 & 34 & 160 \\
\hline 8 & 32 & 156 \\
\hline 9 & 19 & 153 \\
\hline 10 & 33 & 135 \\
\hline 11 & 27 & 126 \\
\hline 12 & 23 & 113 \\
\hline 13 & 2 & 106 \\
\hline 14 & 5 & 104 \\
\hline 15 & 7 & 97 \\
\hline 16 & 22 & 97 \\
\hline 17 & 4 & 88 \\
\hline 18 & 35 & 87 \\
\hline
\end{tabular}




\begin{tabular}{|c|c|c|}
\hline 19 & 40 & 81 \\
\hline 20 & 13 & 77 \\
\hline 21 & 31 & 76 \\
\hline 22 & 12 & 71 \\
\hline 23 & 37 & 70 \\
\hline 24 & 25 & 68 \\
\hline 25 & 17 & 67 \\
\hline 26 & 36 & 66 \\
\hline 27 & 30 & 64 \\
\hline 28 & 29 & 60 \\
\hline 29 & 21 & 59 \\
\hline 30 & 3 & 58 \\
\hline 31 & 6 & 57 \\
\hline 32 & 8 & 57 \\
\hline 33 & 41 & 56 \\
\hline 34 & 9 & 55 \\
\hline 35 & 1 & 49 \\
\hline 36 & 20 & 48 \\
\hline 37 & 10 & 46 \\
\hline 38 & 42 & 45 \\
\hline 39 & 15 & 39 \\
\hline 40 & 11 & 38 \\
\hline 41 & 14 & 34 \\
\hline 42 & 16 & 31 \\
\hline
\end{tabular}

Table 4: Kind of Child Rights Violation Reported

\begin{tabular}{|l|l|l|l|}
\hline S1. No. & Kind of Violation & Yes $(\mathbf{\%})$ & No $(\%)$ \\
\hline 1 & Child labour & 97.2 & 2.8 \\
\hline 2 & Discrimination in school & 94.2 & 5.8 \\
\hline 3 & Street begging & 92.4 & 7.6 \\
\hline 4 & Children deprived of education & 50.2 & 49.8 \\
\hline 5 & Sexually exploited Children & 48.0 & 52.0 \\
\hline 6 & Child abuse & 43.6 & 56.4 \\
\hline 7 & Children in drug trafficking & 38.6 & 61.4 \\
\hline 8 & Child trafficking & 31.0 & 69.0 \\
\hline 9 & Discrimination of children with disability & 30.0 & 70.0 \\
\hline 10 & Discrimination on the basis of caste and religion & 29.4 & 70.6 \\
\hline 11 & Children in conflict with law & 28.4 & 71.6 \\
\hline 12 & Bonded labour children & 28.8 & 71.2 \\
\hline 13 & Gender inequality & 19.6 & 80.4 \\
\hline 14 & Foeticide & 19.2 & 80.8 \\
\hline 15 & Children suffering with chronic diseases/ailments & 16.2 & 83.8 \\
\hline 16 & Others & 3.0 & 97.0 \\
\hline
\end{tabular}


Table 5: Duration of Orientation Programme for Media Personnel

\begin{tabular}{|l|l|l|}
\hline Particulars & $\begin{array}{l}\text { No. of persons } \\
\text { N:500 }\end{array}$ & $\%$ \\
\hline 1Day & 216 & 43.2 \\
\hline 2Days & 158 & 31.6 \\
\hline 3Days & 53 & 10.6 \\
\hline 4Days & 72 & 14.0 \\
\hline
\end{tabular}

Table 6: Medium of Choice of Media personnel in Sensitizing Public on Child Rights

\begin{tabular}{|l|l|l|l|}
\hline S1. No & Medium & Yes $(\%)$ & No $(\%)$ \\
\hline 1 & News papers & 97.4 & 2.6 \\
\hline 2 & Television & 82.2 & 17.8 \\
\hline 3 & Mobile phone & 22.4 & 77.6 \\
\hline 4 & Internet & 25.4 & 74.6 \\
\hline 5 & Folk media & 17.4 & 82.6 \\
\hline 6 & Cinema & 26.4 & 73.6 \\
\hline 7 & Exhibition & 23.4 & 76.6 \\
\hline
\end{tabular}

Table 7: Functions of Mass Media in Protecting and Promoting Child Rights

\begin{tabular}{|l|l|l|l|}
\hline $\begin{array}{l}\text { Sl. } \\
\text { No }\end{array}$ & Functions & Yes (\%) & No (\%) \\
\hline 1 & $\begin{array}{l}\text { Sensitizing the elders with regard to child rights and to bring } \\
\text { positive behavioural change in them. }\end{array}$ & 67.8 & 32.2 \\
\hline 2 & $\begin{array}{l}\text { Incorporating issues concerned with child rights in the school } \\
\text { curriculum along with illustration so as to convey the message } \\
\text { effectively. }\end{array}$ & 71.0 & 29.0 \\
\hline 3 & $\begin{array}{l}\text { Violation of child rights, wherever occurred are to be reported } \\
\text { along with appropriate services and advice. }\end{array}$ & 68.8 & 31.2 \\
\hline 4 & $\begin{array}{l}\text { To aid the official missionary in formulation and also } \\
\text { implementing the policies and programmes related to children. }\end{array}$ & 14.2 & 85.8 \\
\hline
\end{tabular}




\section{Annexure}

UN Convention on the Rights of the Child: A Study on the Perceptions of Media Personnel in Mysuru Division

\begin{tabular}{|c|c|c|}
\hline $\begin{array}{l}\text { Sl. } \\
\text { No }\end{array}$ & Articles & Explanation \\
\hline 1 & Article 1 (Definition of the child): & $\begin{array}{l}\text { The Convention defines a 'child' as a person below the age of } \\
\text { 18, unless the laws of a particular country set the legal age for } \\
\text { adulthood younger. The Committee on the Rights of the Child, } \\
\text { the monitoring body for the Convention, has encouraged States } \\
\text { to review the age of majority if it is set below } 18 \text { and to } \\
\text { increase the level of protection for all children under } 18 \text {. }\end{array}$ \\
\hline 2 & Article 2 (Non-discrimination): & $\begin{array}{l}\text { The Convention applies to all children, whatever their race, } \\
\text { religion or abilities; whatever they think or say, whatever type } \\
\text { of family they come from. It doesn't matter where children } \\
\text { live, what language they speak, what their parents do, whether } \\
\text { they are boys or girls, what their culture is, whether they have a } \\
\text { disability or whether they are rich or poor. No child should be } \\
\text { treated unfairly on any basis. }\end{array}$ \\
\hline 3 & Article 3 (Best interests of the child): & $\begin{array}{l}\text { The best interests of children must be the primary concern in } \\
\text { making decisions that may affect them. All adults should do } \\
\text { what is best for children. When adults make decisions, they } \\
\text { should think about how their decisions will affect children. } \\
\text { This particularly applies to budget, policy and law makers. }\end{array}$ \\
\hline 4 & Article 4 (Protection of rights): & $\begin{array}{l}\text { Governments have a responsibility to take all available } \\
\text { measures to make sure children's rights are respected, } \\
\text { protected and fulfilled. When countries ratify the Convention, } \\
\text { they agree to review their laws relating to children. This } \\
\text { involves assessing their social services, legal, health and } \\
\text { educational systems, as well as levels of funding for these } \\
\text { services. Governments are then obliged to take all necessary } \\
\text { steps to ensure that the minimum standards set by the } \\
\text { Convention in these areas are being met. They must help } \\
\text { families protect children's rights and create an environment } \\
\text { where they can grow and reach their potential. In some } \\
\text { instances, this may involve changing existing laws or creating } \\
\text { new ones. Such legislative changes are not imposed, but come } \\
\text { about through the same process by which any law is created or } \\
\text { reformed within a country. Article } 41 \text { of the Convention points } \\
\text { out the when a country already has higher legal standards than } \\
\text { those seen in the Convention, the higher standards always } \\
\text { prevail. }\end{array}$ \\
\hline 5 & Article 5 (Parental guidance): & $\begin{array}{l}\text { Governments should respect the rights and responsibilities of } \\
\text { families to direct and guide their children so that, as they grow, } \\
\text { they learn to use their rights properly. Helping children to } \\
\text { understand their rights does not mean pushing them to make } \\
\text { choices with consequences that they are too young to handle. } \\
\text { Article } 5 \text { encourages parents to deal with rights issues "in a } \\
\text { manner consistent with the evolving capacities of the child". } \\
\text { The Convention does not take responsibility for children away } \\
\text { from their parents and give more authority to governments. It } \\
\text { does place on governments the responsibility to protect and } \\
\text { assist families in fulfilling their essential role as nurturers of } \\
\text { children. }\end{array}$ \\
\hline 6 & Article 6 (Survival and development): & Children have the right to live. Governments should ensure that \\
\hline
\end{tabular}




\begin{tabular}{|c|c|c|}
\hline & & children survive and develop healthily. \\
\hline 7 & $\begin{array}{l}\text { Article } 7 \text { (Registration, name, } \\
\text { nationality, care): }\end{array}$ & $\begin{array}{l}\text { All children have the right to a legally registered name, } \\
\text { officially recognized by the government. Children have the } \\
\text { right to a nationality (to belong to a country). Children also } \\
\text { have the right to know and, as far as possible, to be cared for } \\
\text { by their parents. }\end{array}$ \\
\hline 8 & Article 8 (Preservation of identity): & $\begin{array}{l}\text { Children have the right to an identity - an official record of } \\
\text { who they are. Governments should respect children's right to a } \\
\text { name, a nationality and family ties. }\end{array}$ \\
\hline 9 & Article 9 (Separation from parents): & $\begin{array}{l}\text { Children have the right to live with their parent(s), unless it is } \\
\text { bad for them. Children whose parents do not live together have } \\
\text { the right to stay in contact with both parents, unless this might } \\
\text { hurt the child. }\end{array}$ \\
\hline 10 & Article 10 (Family reunification): & $\begin{array}{l}\text { Families whose members live in different countries should be } \\
\text { allowed to move between those countries so that parents and } \\
\text { children can stay in contact, or get back together as a family }\end{array}$ \\
\hline 11 & Article 11 (Kidnapping): & $\begin{array}{l}\text { Governments should take steps to stop children being taken out } \\
\text { of their own country illegally. This article is particularly } \\
\text { concerned with parental abductions. The Convention's } \\
\text { Optional Protocol on the sale of children, child prostitution and } \\
\text { child pornography has a provision that concerns abduction for } \\
\text { financial gain. }\end{array}$ \\
\hline 12 & $\begin{array}{l}\text { Article } 12 \text { (Respect for the views of the } \\
\text { child): }\end{array}$ & $\begin{array}{l}\text { When adults are making decisions that affect children, children } \\
\text { have the right to say what they think should happen and have } \\
\text { their opinions taken into account. }\end{array}$ \\
\hline 13 & Article 13 (Freedom of expression): & $\begin{array}{l}\text { Children have the right to get and share information, as long as } \\
\text { the information is not damaging to them or others. In } \\
\text { exercising the right to freedom of expression, children have the } \\
\text { responsibility to also respect the rights, freedoms and } \\
\text { reputations of others. The freedom of expression includes the } \\
\text { right to share information in any way they choose, including by } \\
\text { talking, drawing or writing. }\end{array}$ \\
\hline 14 & $\begin{array}{l}\text { Article } 14 \text { (Freedom of thought, } \\
\text { conscience and religion): }\end{array}$ & $\begin{array}{l}\text { Children have the right to think and believe what they want and } \\
\text { to practice their religion, as long as they are not stopping other } \\
\text { people from enjoying their rights. Parents should help guide } \\
\text { their children in these matters. The Convention respects the } \\
\text { rights and duties of parents in providing religious and moral } \\
\text { guidance to their children. Religious groups around the world } \\
\text { have expressed support for the Convention, which indicates } \\
\text { that it in no way prevents parents from bringing their children } \\
\text { up within a religious tradition. At the same time, the } \\
\text { Convention recognizes that as children mature and are able to } \\
\text { form their own views, some may question certain religious } \\
\text { practices or cultural traditions. The Convention supports } \\
\text { children's right to examine their beliefs, but it also states that } \\
\text { their right to express their beliefs implies respect for the rights } \\
\text { and freedoms of others }\end{array}$ \\
\hline 15 & Article 15 (Freedom of association): & $\begin{array}{l}\text { Children have the right to meet together and to join groups and } \\
\text { organizations, as long as it does not stop other people from } \\
\text { enjoying their rights. In exercising their rights, children have } \\
\text { the responsibility to respect the rights, freedoms and } \\
\text { reputations of others. }\end{array}$ \\
\hline 16 & Article 16 (Right to privacy): & $\begin{array}{l}\text { Children have a right to privacy. The law should protect them } \\
\text { from attacks against their way of life, their good name, their } \\
\text { families and their homes. }\end{array}$ \\
\hline
\end{tabular}




\begin{tabular}{|c|c|c|}
\hline 17 & $\begin{array}{l}\text { Article } 17 \text { (Access to information; } \\
\text { mass media): }\end{array}$ & $\begin{array}{l}\text { Children have the right to get information that is important to } \\
\text { their health and well-being. Governments should encourage } \\
\text { mass media - radio, television, newspapers and Internet } \\
\text { content sources - to provide information that children can } \\
\text { understand and to not promote materials that could harm } \\
\text { children. Mass media should particularly be encouraged to } \\
\text { supply information in languages that minority and indigenous } \\
\text { children can understand. Children should also have access to } \\
\text { children's books. }\end{array}$ \\
\hline 18 & $\begin{array}{l}\text { Article } 18 \text { (Parental responsibilities; } \\
\text { state assistance): }\end{array}$ & $\begin{array}{l}\text { Both parents share responsibility for bringing up their children, } \\
\text { and should always consider what is best for each child. } \\
\text { Governments must respect the responsibility of parents for } \\
\text { providing appropriate guidance to their children - the } \\
\text { Convention does not take responsibility for children away from } \\
\text { their parents and give more authority to governments. It places } \\
\text { a responsibility on governments to provide support services to } \\
\text { parents, especially if both parents work outside the home. }\end{array}$ \\
\hline 19 & $\begin{array}{l}\text { Article } 19 \text { (Protection from all forms of } \\
\text { violence): }\end{array}$ & $\begin{array}{l}\text { Children have the right to be protected from being hurt and } \\
\text { mistreated, physically or mentally. Governments should ensure } \\
\text { that children are properly cared for and protect them from } \\
\text { violence, abuse and neglect by their parents, or anyone else } \\
\text { who looks after them. In terms of discipline, the Convention } \\
\text { does not specify what forms of punishment parents should use. } \\
\text { However any form of discipline involving violence is } \\
\text { unacceptable. There are ways to discipline children that are } \\
\text { effective in helping children learn about family and social } \\
\text { expectations for their behaviour - ones that are non-violent, are } \\
\text { appropriate to the child's level of development and take the best } \\
\text { interests of the child into consideration. In most countries, laws } \\
\text { already define what sorts of punishments are considered } \\
\text { excessive or abusive. It is up to each government to review } \\
\text { these laws in light of the Convention. }\end{array}$ \\
\hline 20 & $\begin{array}{l}\text { Article } 20 \text { (Children deprived of family } \\
\text { environment): }\end{array}$ & $\begin{array}{l}\text { Children who cannot be looked after by their own family have } \\
\text { a right to special care and must be looked after properly, by } \\
\text { people who respect their ethnic group, religion, culture and } \\
\text { language. }\end{array}$ \\
\hline 21 & Article 21 (Adoption): & $\begin{array}{l}\text { Children have the right to care and protection if they are } \\
\text { adopted or in foster care. The first concern must be what is best } \\
\text { for them. The same rules should apply whether they are } \\
\text { adopted in the country where they were born, or if they are } \\
\text { taken to live in another country. }\end{array}$ \\
\hline 22 & Article 22 (Refugee children): & $\begin{array}{l}\text { Children have the right to special protection and help if they } \\
\text { are refugees (if they have been forced to leave their home and } \\
\text { live in another country), as well as all the rights in this } \\
\text { Convention }\end{array}$ \\
\hline 23 & Article 23 (Children with disabilities): & $\begin{array}{l}\text { Children who have any kind of disability have the right to } \\
\text { special care and support, as well as all the rights in the } \\
\text { Convention, so that they can live full and independent lives. }\end{array}$ \\
\hline 24 & Article 24 (Health and health services): & $\begin{array}{l}\text { Children have the right to good quality health care }- \text { the best } \\
\text { health care possible - to safe drinking water, nutritious food, a } \\
\text { clean and safe environment, and information to help them stay } \\
\text { healthy. Rich countries should help poorer countries achieve } \\
\text { this. }\end{array}$ \\
\hline 25 & $\begin{array}{l}\text { Article } 25 \text { (Review of treatment in } \\
\text { care): }\end{array}$ & $\begin{array}{l}\text { Children who are looked after by their local authorities, rather } \\
\text { than their parents, have the right to have these living } \\
\text { arrangements looked at regularly to see if they are the most }\end{array}$ \\
\hline
\end{tabular}




\begin{tabular}{|c|c|c|}
\hline & & $\begin{array}{l}\text { appropriate. Their care and treatment should always be based } \\
\text { on "the best interests of the child". (see Guiding Principles, } \\
\text { Article 3) }\end{array}$ \\
\hline 26 & Article 26 (Social security): & $\begin{array}{l}\text { Children - either through their guardians or directly - have the } \\
\text { right to help from the government if they are poor or in need. }\end{array}$ \\
\hline 27 & $\begin{array}{l}\text { Article } 27 \text { (Adequate standard of } \\
\text { living): }\end{array}$ & $\begin{array}{l}\text { Children have the right to a standard of living that is good } \\
\text { enough to meet their physical and mental needs. Governments } \\
\text { should help families and guardians who cannot afford to } \\
\text { provide this, particularly with regard to food, clothing and } \\
\text { housing. }\end{array}$ \\
\hline 28 & Article 28: (Right to education): & $\begin{array}{l}\text { All children have the right to a primary education, which } \\
\text { should be free. Wealthy countries should help poorer countries } \\
\text { achieve this right. Discipline in schools should respect } \\
\text { children's dignity. For children to benefit from education, } \\
\text { schools must be run in an orderly way - without the use of } \\
\text { violence. Any form of school discipline should take into } \\
\text { account the child's human dignity. Therefore, governments } \\
\text { must ensure that school administrators review their discipline } \\
\text { policies and eliminate any discipline practices involving } \\
\text { physical or mental violence, abuse or neglect. The Convention } \\
\text { places a high value on education. Young people should be } \\
\text { encouraged to reach the highest level of education of which } \\
\text { they are capable. }\end{array}$ \\
\hline 29 & Article 29 (Goals of education): & $\begin{array}{l}\text { Children's education should develop each child's personality, } \\
\text { talents and abilities to the fullest. It should encourage children } \\
\text { to respect others, human rights and their own and other } \\
\text { cultures. It should also help them learn to live peacefully, } \\
\text { protect the environment and respect other people. Children } \\
\text { have a particular responsibility to respect the rights their } \\
\text { parents, and education should aim to develop respect for the } \\
\text { values and culture of their parents. The Convention does not } \\
\text { address such issues as school uniforms, dress codes, the } \\
\text { singing of the national anthem or prayer in schools. It is up to } \\
\text { governments and school officials in each country to determine } \\
\text { whether, in the context of their society and existing laws, such } \\
\text { matters infringe upon other rights protected by the Convention. }\end{array}$ \\
\hline 30 & $\begin{array}{l}\text { Article } 30 \text { (Children of } \\
\text { minorities/indigenous groups): }\end{array}$ & $\begin{array}{l}\text { Minority or indigenous children have the right to learn about } \\
\text { and practice their own culture, language and religion. The right } \\
\text { to practice one's own culture, language and religion applies to } \\
\text { everyone; the Convention here highlights this right in instances } \\
\text { where the practices are not shared by the majority of people in } \\
\text { the country. }\end{array}$ \\
\hline 31 & Article 31 (Leisure, play and culture): & $\begin{array}{l}\text { Children have the right to relax and play, and to join in a wide } \\
\text { range of cultural, artistic and other recreational activities. }\end{array}$ \\
\hline 32 & Article 32 (Child labour): & $\begin{array}{l}\text { The government should protect children from work that is } \\
\text { dangerous or might harm their health or their education. While } \\
\text { the Convention protects children from harmful and exploitative } \\
\text { work, there is nothing in it that prohibits parents from } \\
\text { expecting their children to help out at home in ways that are } \\
\text { safe and appropriate to their age. If children help out in a } \\
\text { family farm or business, the tasks they do be safe and suited to } \\
\text { their level of development and comply with national labour } \\
\text { laws. Children's work should not jeopardize any of their other } \\
\text { rights, including the right to education, or the right to } \\
\text { relaxation and play. }\end{array}$ \\
\hline 33 & Article 33 (Drug abuse): & $\begin{array}{l}\text { Governments should use all means possible to protect children } \\
\text { from the use of harmful drugs and from being used in the drug }\end{array}$ \\
\hline
\end{tabular}




\begin{tabular}{|c|c|c|}
\hline & & trade \\
\hline 34 & Article 34 (Sexual exploitation): & $\begin{array}{l}\text { Governments should protect children from all forms of sexual } \\
\text { exploitation and abuse. This provision in the Convention is } \\
\text { augmented by the Optional Protocol on the sale of children, } \\
\text { child prostitution and child pornography. }\end{array}$ \\
\hline 35 & $\begin{array}{l}\text { Article } 35 \text { (Abduction, sale and } \\
\text { trafficking): }\end{array}$ & $\begin{array}{l}\text { The government should take all measures possible to make } \\
\text { sure that children are not abducted, sold or trafficked. This } \\
\text { provision in the Convention is augmented by the Optional } \\
\text { Protocol on the sale of children, child prostitution and child } \\
\text { pornography. }\end{array}$ \\
\hline 36 & $\begin{array}{l}\text { Article } 36 \text { (Other forms of } \\
\text { exploitation): }\end{array}$ & $\begin{array}{l}\text { Children should be protected from any activity that takes } \\
\text { advantage of them or could harm their welfare and } \\
\text { development. }\end{array}$ \\
\hline 37 & Article 37 (Detention and punishment): & $\begin{array}{l}\text { No one is allowed to punish children in a cruel or harmful way. } \\
\text { Children who break the law should not be treated cruelly. They } \\
\text { should not be put in prison with adults, should be able to keep } \\
\text { in contact with their families, and should not be sentenced to } \\
\text { death or life imprisonment without possibility of release. }\end{array}$ \\
\hline 38 & Article 38 (War and armed conflicts): & $\begin{array}{l}\text { Governments must do everything they can to protect and care } \\
\text { for children affected by war. Children under } 15 \text { should not be } \\
\text { forced or recruited to take part in a war or join the armed } \\
\text { forces. The Convention's Optional Protocol on the involvement } \\
\text { of children in armed conflict further develops this right, raising } \\
\text { the age for direct participation in armed conflict to } 18 \text { and } \\
\text { establishing a ban on compulsory recruitment for children } \\
\text { under } 18 \text {. }\end{array}$ \\
\hline 39 & $\begin{array}{l}\text { Article } 39 \text { (Rehabilitation of child } \\
\text { victims): }\end{array}$ & $\begin{array}{l}\text { Children who have been neglected, abused or exploited should } \\
\text { receive special help to physically and psychologically recover } \\
\text { and reintegrate into society. Particular attention should be paid } \\
\text { to restoring the health, self-respect and dignity of the child. }\end{array}$ \\
\hline 40 & Article 40 (Juvenile justice): & $\begin{array}{l}\text { Children who are accused of breaking the law have the right to } \\
\text { legal help and fair treatment in a justice system that respects } \\
\text { their rights. Governments are required to set a minimum age } \\
\text { below which children cannot be held criminally responsible } \\
\text { and to provide minimum guarantees for the fairness and quick } \\
\text { resolution of judicial or alternative proceedings. }\end{array}$ \\
\hline 41 & $\begin{array}{l}\text { Article } 41 \text { (Respect for superior } \\
\text { national standards): }\end{array}$ & $\begin{array}{l}\text { If the laws of a country provide better protection of children's } \\
\text { rights than the articles in this Convention, those laws should } \\
\text { apply. }\end{array}$ \\
\hline 42 & Article 42 (Knowledge of rights): & $\begin{array}{l}\text { Governments should make the Convention known to adults and } \\
\text { children. Adults should help children learn about their rights, } \\
\text { too. (See also article } 4 \text {.) }\end{array}$ \\
\hline
\end{tabular}

